\title{
DEPTH EFFECT ON QUALITY CHARACTERISTICS OF TRADITIONAL SALTED-RIPENED ANCHOVY (ENGRAULIS ENCRASICOLUS) TAKEN FROM DIFFERENT PARTS OF THE SAME BARREL
}

\author{
Rima Ayad $^{1 凶}$, Tayeb Idoui', Houria Ouled Haddar ${ }^{2}$, and Susana Valenzuela ${ }^{3,4}$ \\ ${ }^{1}$ University Mohamed Seddik Benyahia of Jijel, Faculty of Nature and Life Sciences, Department of Applied \\ Microbiology and Food Science, Laboratory of Biotechnology, Environment and Health, PB 98 Ouled Ä̈ssa, \\ 18000, Jijel, Algeria. \\ ${ }^{2}$ University Mohamed Seddik Benyahia of Jijel, Faculty of Nature and Life Sciences, Department of Applied \\ Microbiology and Food Science, Laboratory of Molecular Toxicology, PB 98 Ouled Aïssa, 18000, Jijel, Algeria. \\ ${ }^{3}$ University of Barcelona, Faculty of Biology, Department of Genetics, Microbiology and Statistics, Av. \\ Diagonal 643, 08028, Barcelona, Spain. \\ ${ }^{4}$ University of Barcelona, Institute of Nanoscience and Nanotechnology (IN2UB), Spain. \\ $\otimes_{\text {ryma.mahfoud@hotmail.fr }}$ \\ https://doi.org/10.34302/crpjfst/2021.13.4.6 \\ Article history: \\ Received: \\ 24 July 2021 \\ Accepted: \\ 7 November 2021 \\ Keywords: \\ Salted-ripened anchovy; \\ Depth effect; \\ Same barrel; \\ Approximate composition \\ Quality characteristics.

\section{ABSTRACT} \\ Samples from different depths of the same barrel of traditionally-produced \\ salted anchovies (Engraulis encrasicolus) were assessed in terms of \\ approximate composition, physicochemical, microbial and sensory \\ attributes, underlining a new concept of "depth effect". \\ All samples showed low protein content, high levels of ash and salt, and a \\ wide variation in moisture, total lipids, and dry matter contents. Saturated \\ fatty acids were the most prevalent in all samples. Polyunsaturated fatty \\ acids increased as depth increased. Zinc (Zn) was the main mineral noticed \\ in all samples, followed by iron (Fe). \\ Microbiological analysis revealed a gradual increase in halophilic bacterial \\ count from the surface to the bottom of the barrel. In terms of organoleptic \\ properties, all samples were rated as regular, corresponding to a semi- \\ ripened product. There was a depth effect on the overall quality \\ characteristics of the fish, mainly related to the effect of pressure on the \\ anchovy salting and ripening process.
}

\section{Introduction}

The anchovy (Engraulis encrasicolus) is a small pelagic species that belongs to the Engraulidae family. It is characterized by a very slim body and the standard color of pelagic fish: a dark back to hide from birds, and a silver belly, that looks like the water's surface once seen from below (Pons-Sánchez-Cascado et al., 2006).

Because of their abundance, anchovies have been caught and eaten by humans for a long time, and of the seventeen current genera, Engraulis, Anchoa, and Stolephorusare the most commercially important (FAO, 2014).
The European anchovy features a high commercial worth and represents the foremost valuable pelagic fish resource in the Mediterranean Sea (Lleonart and Maynou, 2003).

Fresh anchovies are still in high demand in markets, even though there is an increasing orientation toward manufacturing prepared and preserved products. This fish is often consumed fresh during spring and summer time, or marinated in vinegar and ripened in saturated brines. Fish salting and ripening is a widespread and traditional practice utilized in European countries to lengthen different fish 
species' shelf-life, like Atlantic herring (Clupea harengus), sprats (Sprattus sprattus), sardine (Sardina pilchardus), and anchovy (Engraulis encrasicolus). Among these varieties of products, salted and ripened anchovy has major importance in the worldwide market (Czerner and Yeannes, 2013). This salting and ripening process is mostly carried out, taking into consideration product safety and quality parameters. However, it is critical to understand the proximate composition of fish species in the application of various technological processes and as an aspect of raw material quality, sensory attributes, and storage stability (Huss, 1988; Sikorski et al., 1990).

The main objective of the present study was to assess and compare the quality of samples taken from three different depths of the same barrel of salted anchovies (Engraulis encrasicolus) produced using a traditional method, by evaluating their proximate composition, physicochemical, microbial, and sensory characteristics. The concept of the depth effect on the whole quality characteristics of the traditional salted-ripened European anchovy is being studied for the first time in this work.

\section{Materials and methods}

\subsection{Preparation of salted-ripened anchovy and sample collection}

Samples of salted anchovies prepared in an artisanal way were collected from the Jijelian (Algerian North-East) fish market and placed in thick-walled polystyrene boxes, packed in an icebox and delivered to the processing laboratory on the same day.

This artisanal method is a preliminary step in the wet salting process, which involves placing whole anchovies in bins and immersing them in saturated brine for 10 days. When compared to raw fish, water activity (aw) is reduced by 15 to $19 \%$ during this stage (Filsinger, 1987). Anchovies are beheaded, gutted, and placed in a $25 \mathrm{~kg}$ barrel alternating layers of fish and salt with a final salt-to-fish ratio of 1:3. Finally, the barrel is closed, and weights are set on top of the lid to press down on the salt and anchovies. After pressing, they are left in the barrel for four months at room temperature, until they have developed a reddish color and the wanted aroma.

To get reliable representation, three samples of $1 \mathrm{~kg}$ of salted anchovies were selected at random in triplicate and taken from three different parts (from top to bottom) of the same barrel:

Sample S: from the top of the barrel (at $5 \pm 2$ $\mathrm{cm})$

Sample I: from the middle of the barrel (at $15 \pm$ $2 \mathrm{~cm}$ )

Sample D: from the bottom of the barrel (at 30 $\pm 2 \mathrm{~cm})$.

Physical characteristics of the raw material (fresh anchovy) were determined by measuring the total length, weight, and number of fish pieces in $1 \mathrm{~kg}$ of each sample.

\subsection{Proximate composition and physicochemical analysis}

Salted anchovy was analyzed to determine chemical proximate composition. For this, all samples were analyzed for their protein, fat, moisture, dry matter and ash contents by standard analytical procedures of the Association of Official Agricultural Chemists, AOAC. The analysis was performed in triplicate and the average values were calculated and expressed as mean $\pm \mathrm{SD}$ of triplicate observations.

Salted fish samples $\left(\begin{array}{ll}10 & \mathrm{~g}\end{array}\right)$ were homogenized for $5 \mathrm{~min}$ in sterile blenders with $10 \mathrm{~mL}$ of distilled water to form a thick slurry. The slurry's $\mathrm{pH}$ was determined using a Hanna Hi $2210 \mathrm{pH}$ meter (Hanna Glass Works, Medfield, MA) (AOAC, 2000).

To determine salt content in each sample (AOAC, 1995), $2 \mathrm{~g}$ of sample were homogenized with $18 \mathrm{~mL}$ of distilled water before being titrated with $0.1 \mathrm{M} \mathrm{AgNO}_{3}$ using $10 \%(\mathrm{w} / \mathrm{v}) \mathrm{K}_{2} \mathrm{CrO}_{4}$ solution as the indicator.

The moisture content was calculated by subtracting the fresh and dry weights of samples after drying them at $105 \pm 1^{\circ} \mathrm{C}$ until they reached constant weight (AOAC, 1990). Crude protein, as the total nitrogen content, was 
determined by the Kjeldahl method (AOAC, 1995). Crude fat was measured from the dried sample by Soxhlet extraction with petroleum ether (AOAC, 1995). And the crude ash fraction was obtained by incinerating the organic matter at $550{ }^{\circ} \mathrm{C}$ for about five hours until the sample was free from carbon particles (AOAC, 1990). Total titratable acidity (TTA) was determined by titrating against $0.1 \mathrm{M}$ $\mathrm{NaOH}$, and acidity was calculated as the percentage of lactic acid (AOAC, 1995). The peroxide index (PV) and the content of free fatty acids (FFA) or acid value were determined on the chloroform extracts of tissues (AOAC, 2000). The saponification index was measured according to the American Oil Chemists' Society (AOCS, 1993), where 1 $\mathrm{g}$ of ground sample was dissolved in $1.0 \mathrm{M}$ alcoholic $\mathrm{KOH}$ and boiled gently but steadily in a water bath for $30 \mathrm{~min}$ for complete saponification. The solution was then titrated with $0.5 \mathrm{M} \mathrm{HCl}$ using phenolphthalein as an indicator. A blank determination was carried out concurrently with the sample.

For mineral composition, the ash solution of each sample in $10 \mathrm{~mL}$ of distilled water was hydrolyzed with $1 \mathrm{~mL}$ of $\mathrm{HCl}$ and boiled for 5 min in a water bath until the complete dissolution of ashes. The obtained solution was transferred into a $100 \mathrm{~mL}$ graduated flask where the volume is completed in 100 by adding distilled water (NF V04-404, 2001). From this final solution, lead $(\mathrm{Pb})$, iron $(\mathrm{Fe})$, chromium $(\mathrm{Cr})$, manganese $(\mathrm{Mn})$, copper $(\mathrm{Cu})$, zinc $(\mathrm{Zn})$, and cadmium $(\mathrm{Cd})$ content were analyzed by atomic absorption spectrometry (Shimadzu AA-6200).

The fatty acid composition was determined in accordance with NF EN ISO 12966-4: 2015, which requires two preliminary stages, fatty acid extraction and esterification: $20 \mathrm{~g}$ of each lipid extract sample obtained previously using the Soxhlet method, were dissolved in $0.5 \mathrm{~mL}$ heptane and $0.2 \mathrm{~mL}$ of methanolic $2 \mathrm{M} \mathrm{KOH}$ was added. The mixture was boiled in a water bath for $2 \mathrm{~min}$ and $0.2 \mathrm{~mL}$ of $2 \mathrm{M} \mathrm{HCl}$ was added. After vigorous shaking and decantation, $100 \mu \mathrm{L}$ of the upper phase was evaporated and the residue was reconstituted in $50 \mu \mathrm{L}$ of heptane until the upper phase became clear and then injected into a gas chromatograph. The fatty acid methyl esters were analyzed by GC/MS on a Shimadzu QP2010 GC/MS equipped with a capillary column SE30 (30 m x $0.25 \mathrm{~mm}$ i.d., $0.25 \mu \mathrm{m}$ film thickness) and helium as the carrier gas at a flow rate of 0.76 $\mathrm{mL} / \mathrm{min}$. Samples were injected into the split mode. The column was kept at $140{ }^{\circ} \mathrm{C}$ for 10 $\min$ and then programmed to increase by 1 ${ }^{\circ} \mathrm{C} /$ min up to $160{ }^{\circ} \mathrm{C}$, then by $2{ }^{\circ} \mathrm{C} /$ min up to $220{ }^{\circ} \mathrm{C}$ then maintained for $15 \mathrm{~min}$. By examining the elution order on the column and comparing the retention times to those of pure standards, the gas chromatogram peaks were identified as corresponding fatty acid methyl esters.

\subsection{Microbiological analysis}

Salted-ripened anchovies flesh was chopped and ground for 1 min using a Warning Commercial Blender (USA). Each sample (10 g) was collected aseptically and homogenized mechanically in $90 \mathrm{~mL}$ of sterile salt broth (meat extract, $3 \mathrm{~g} / \mathrm{L}$; meat peptone, $5 \mathrm{~g} / \mathrm{L}$; $\mathrm{NaCl}, 150 \mathrm{~g} / \mathrm{L}$ ) (ICMSF, 1983). As an enrichment step, the homogenate was incubated at $35-37{ }^{\circ} \mathrm{C}$ for $30 \mathrm{~min}$ to recover stressed cells. Following that, decimal dilutions $\left(10^{-1}, 10^{-2}, 10^{-}\right.$ ${ }^{3}, 10^{-4}$, and $10^{-5}$ ) of the same solution were prepared and spread in the growth media. Plate Count Agar (PCA) incubated at $30^{\circ} \mathrm{C}$ for $48 \mathrm{~h}$ for aerobic mesophilic bacteria, Violet, Red Bile Lactose agar (VRBL) incubated at $30{ }^{\circ} \mathrm{C}$ and $44{ }^{\circ} \mathrm{C}$ for $24-48 \mathrm{~h}$ for total and thermotolerant coliforms, respectively, Man Rogosa-Sharpe agar (MRS) incubated at $37{ }^{\circ} \mathrm{C}$ for 48-72 $\mathrm{h}$ for lactic acid bacteria, Chapman agar incubated at $37{ }^{\circ} \mathrm{C}$ for $48 \mathrm{~h}$ for staphylococci, Meat-Liver agar incubated at 46 ${ }^{\circ} \mathrm{C}$ for $24-48 \mathrm{~h}$ for sulfito-reducing Clostridium, Oxytetracycline Glucose Agar (OGA) at $25^{\circ} \mathrm{C}$ for 5 days for yeasts and moulds (AOAC, 1995; NF ISO 4832: 2006).

The halophilic bacteria count was determined using the Halophilic Medium (HM) of Torreblanca et al. (1986) containing (per 
liter of distilled water): $5 \mathrm{~g}$ peptone (Difco), $5 \mathrm{~g}$ yeast extract (Difco), $22 \mathrm{~g}$ agar at two final total salt concentrations of $5 \%$ and $10 \%$ $(\mathrm{w} / \mathrm{v})$. The stock solution of total salts of $30 \%$ (w/v) was prepared as described by Subov (1931): (NaCl, $234 \mathrm{~g} ; \mathrm{MgCl}_{2} .6 \mathrm{H}_{2} \mathrm{O}, 42 \mathrm{~g}$; $\mathrm{MgSO}_{4} .7 \mathrm{H}_{2} \mathrm{O}, 60 \mathrm{~g} ; \mathrm{KCl}, 6 \mathrm{~g} ; \mathrm{CaCl}_{2} .2 \mathrm{H}_{2} \mathrm{O}, 1 \mathrm{~g}$; $\mathrm{NaBr}, 0.7 \mathrm{~g} ; \mathrm{NaHCO}_{3}, 0.2 \mathrm{~g} ; \mathrm{FeCl}_{3}, 0.005 \mathrm{~g}$ and $1000 \mathrm{~mL}$ of distilled water). The enumeration of these microorganisms was performed in duplicate and the mean value of each count was expressed as the number of colony-forming units/g (CFU/g).

\subsection{Sensory assessments}

A sensory evaluation of the ripening progress was performed by a six-member trained panel using the Table proposed by Filsinger et al. (1982) in which the parameters flavor, odor, flesh color, flesh consistency, and flesh adhering to the backbone are assessed using an 8-point quality scale. Each factor was assigned a score to the fish based on the descriptions in the table. The fish's score was determined by taking the average of the five factors. The maturation scale's minimum value is zero, representing the sensory characteristics of raw fish just before the ripening process begins. Point 6 denoted the optimal level of ripening, while point 8 denoted spoilt or overripe anchovies.

\subsection{Statistical analysis}

The data were subjected to one-way analysis of variance and expressed as the mean \pm the standard deviation (SD). The Statistical Package for Social Sciences, version 23.0, was used for all statistical analyses (SPSS for Windows; SPSS Inc., Chicago, IL). The significance level for differences was defined at $p<0.01$.

\section{Results and discussions}

\subsection{Physical characteristics of raw fish}

The characteristics of fish used in the present investigation in terms of length, weight, and the number of pieces in $1 \mathrm{~kg}$ are shown in Table 1. The average length of the fish in the current study was almost the same for all the three samples $(13 \pm 0.00$ to $13 \pm 0.82 \mathrm{~cm})$, though the average weight varied slightly, indicating their sexual and seasonal maturity. These values are lower than those found by Simat and Bogdanović (2012) who recorded an average length of $15.23 \pm 0.68 \mathrm{~cm}$ and an average weight of $24.72 \pm 3.64 \mathrm{~g}$, and higher than those found by Sofoulaki et al. (2018) who registered an average length between $8.71 \pm$ $0.46 \mathrm{~cm}$ and $11.33 \pm 0.52 \mathrm{~cm}$ and an average weight between $3.9 \pm 0.6 \mathrm{~g}$ and $8.2 \pm 1.3 \mathrm{~g}$.

Table 1. Quality characteristics of different anchovy samples.

\begin{tabular}{|l|c|c|c|}
\hline \multirow{2}{*}{ Characteristics } & \multicolumn{3}{c|}{ Samples } \\
\cline { 2 - 4 } & S & I & D \\
\hline \multicolumn{2}{|c|}{ Physical characteristics of fresh anchovies } \\
\hline Length (cm) & $13 \pm 0.82^{\mathrm{a}}$ & $13 \pm 0.00^{\mathrm{b}}$ & $13 \pm 0.00^{\mathrm{c}}$ \\
\hline Weight (g) & $13.4 \pm 2.97^{\mathrm{a}}$ & $13 \pm 0.71^{\mathrm{a}}$ & $13.5 \pm 1.73^{\mathrm{a}}$ \\
\hline Number of fish pieces in 1 kg & $70 \pm 1.00^{\mathrm{a}}$ & $66 \pm 0.57^{\mathrm{a}}$ & $66 \pm 0.57^{\mathrm{a}}$ \\
\hline \multicolumn{2}{|c|}{ Physicochemical characteristics } \\
\hline pH & $5.81 \pm 0.04^{\mathrm{a}}$ & $5.75 \pm 0.03^{\mathrm{b}}$ & $5.66 \pm 0.02^{\mathrm{c}}$ \\
\hline TTA ( $\left.{ }^{\mathrm{a}} \mathbf{m}\right)$ & $0.06 \pm 0.1^{\mathrm{a}}$ & $0.06 \pm 0.1^{\mathrm{a}}$ & $0.08 \pm 0.1^{\mathrm{a}}$ \\
\hline Moisture (\%) & $57.5 \pm 0.1^{\mathrm{a}}$ & $55.0 \pm 0.2^{\mathrm{b}}$ & $52.5 \pm 0.1^{\mathrm{c}}$ \\
\hline Dry matter (\%) & $42.5 \pm 0.1^{\mathrm{b}}$ & $45.0 \pm 0.2^{\mathrm{a}}$ & $47.5 \pm 0.1^{\mathrm{c}}$ \\
\hline Crude protein (\%) & $1.37 \pm 0.63^{\mathrm{a}}$ & $1.32 \pm 0.19^{\mathrm{a}}$ & $1.28 \pm 0.35^{\mathrm{a}}$ \\
\hline Total lipid (\%) & $4.25 \pm 0.08^{\mathrm{b}}$ & $4.69 \pm 0.12^{\mathrm{a}}$ & $5.38 \pm 0.15^{\mathrm{c}}$ \\
\hline Ash (\%) & $35.0 \pm 0.1^{\mathrm{a}}$ & $36.0 \pm 0.3^{\mathrm{b}}$ & $40.5 \pm 0.1^{\mathrm{c}}$ \\
\hline
\end{tabular}




\begin{tabular}{|c|c|c|c|}
\hline Salt (\%) & $34.7 \pm 0.9^{\mathrm{a}}$ & $35.1 \pm 0.2^{b}$ & $40.3 \pm 0.3^{\mathrm{c}}$ \\
\hline $\mathrm{PV}$ (meq $\mathrm{O}_{2} / \mathrm{kg}$ of fat) & $0.5 \pm 0.00^{\mathrm{a}}$ & $0.5 \pm 0.00^{b}$ & $0.75 \pm 0.05^{\mathrm{c}}$ \\
\hline FFA (\% of Oleic acid) & $5.74 \pm 0.5^{\mathrm{a}}$ & $7.17 \pm 0.5^{\mathrm{a}}$ & $7.89 \pm 1.0^{\mathrm{a}}$ \\
\hline $\begin{array}{l}\text { Saponification index } \\
(\mathrm{mg} \mathrm{KOH} / \mathrm{g})\end{array}$ & $102.38 \pm 0.7^{\mathrm{a}}$ & $75.73 \pm 0.4^{b}$ & $91.27 \pm 0.5^{\mathrm{c}}$ \\
\hline \multicolumn{4}{|c|}{ Microbiological characteristics (CFU/g) } \\
\hline Total plate count & $4.0 \times 10^{4} \pm 1.05^{\mathrm{a}}$ & $3.3 \times 10^{4} \pm 0.07^{b}$ & $2.0 \times 10^{4} \pm 1.00^{\mathrm{c}}$ \\
\hline Total coliforms & 00 & 00 & 00 \\
\hline Thermotolerant coliforms & 00 & 00 & 00 \\
\hline Lactic acid bacteria & $1 \times 10^{6} \pm 0.7^{\mathrm{a}}$ & $2.7 \times 10^{6} \pm 1,27^{\mathrm{a}}$ & $1.32 \times 10^{7} \pm 0.13^{\mathrm{a}}$ \\
\hline Staphylococci & Abs & Abs & Abs \\
\hline Sulfito-reducing Clostridium & 00 & 00 & 00 \\
\hline Yeasts and moulds & 10 & 00 & 00 \\
\hline $\begin{array}{l}\text { Halophilic count } \\
5 \% \\
10 \% \\
\end{array}$ & $\begin{array}{l}1.23 \times 10^{3} \pm 0.83^{\mathrm{a}} \\
1.12 \times 10^{3} \pm 1.00^{\mathrm{a}}\end{array}$ & $\begin{array}{l}2.40 \times 10^{3} \pm 0.12^{\mathrm{b}} \\
1.21 \times 10^{3} \pm 0.05^{\mathrm{b}}\end{array}$ & $\begin{array}{l}2.64 \times 10^{3} \pm 0.55^{\mathrm{c}} \\
1.43 \times 10^{3} \pm 0.59^{\mathrm{c}}\end{array}$ \\
\hline \multicolumn{4}{|c|}{ Sensory characteristics } \\
\hline Mean scores & $3.76 \pm 0.5^{\mathrm{a}}$ & $3.12 \pm 1.05^{\mathrm{b}}$ & $4.08 \pm 0.09^{c}$ \\
\hline
\end{tabular}

S: Sample taken from the Superficial part, I: Sample taken from the Intermediate part, D: Sample taken from the Deep part. TTA: Total Titratable Acidity, PV: Peroxide Value, FFA: Free Fatty Acid, CFU: Colony Forming Unit, Abs: Absence.

${ }^{\mathrm{a}-\mathrm{c}}$ Values in the same line and labelled with different letters differ significantly $(p<0.01)$.

Besides, the number of fish pieces in $1 \mathrm{~kg}$ of each sample, was $70 \pm 1.00,66 \pm 0.57$, and $66 \pm 0.57$ pieces for the samples S, I, D, respectively. According to Arrignon (1966), 1 $\mathrm{kg}$ of anchovy has to contain 50 elements of fish. These elements measure between 8 and 19 $\mathrm{cm}$ and have an average length and an average weight of $14 \mathrm{~cm}$ and $20 \mathrm{~g}$, respectively. Our results correlate with this data regarding length. However, the average weight was lower with a difference of about $6 \mathrm{~g}$, which explains the low number of fish pieces in $1 \mathrm{~kg}$. The number of elements may be decreased, thereby decreasing the total mass of the elements.

\subsection{Proximate composition and physicochemical analysis}

The $\mathrm{pH}$ values were significantly different in the three samples $(p<0.01)$. There was no significant difference between TTA values $(p>$ $0.01)$. These results are in agreement with most of the reported literature data (HernándezHerrero et al., 1999; 2002; Llorente Holgado et al., 2007; Ababouch and El Marrakchi, 2009). According to Ababouch and El Marrakchi
(2009), the $\mathrm{pH}$ of anchovy muscle decreased from 6 to 5.4 after 3-4 months of the ripening process. This decrease, which is essentially attributed to the accumulation of free fatty acids, is made in spite of a significant increase in nitrogenous bases, in particular $\mathrm{NH}_{3}$. On the other hand, the reason for the lower $\mathrm{pH}$ values of the product may also be attributed to the fact that the samples were fermenting rather than spoiling. In the same analogy, the high value of TTA seemed to be due to the production of various organic acids, including free fatty acids. This implies that the fish underwent sufficient fermentation with endogenous and/or exogenous (microbial) enzyme systems (Majumdar and Basu, 2010).

The significant differences in $\mathrm{pH}$ values between the three samples could be also explained by the difference in salt concentration and depth from where each sample was collected. It has been suggested that salt concentration influences not only water activity, but also the $\mathrm{pH}$ (Rodríguez-Jerez et al., 1993; Hernández-Herrero et al., 1999). The decrease in $\mathrm{pH}$ value is explained by the 
increase of the ionic strength of the solution within the cells (Goulas and Kontominas, 2005; Ormanci and Colakoglu, 2015).

The peroxide and saponification indexes showed a significant variation in the three samples $(p<0.01)$. The FFA content was in the range of $5.74 \pm 0.50-7.89 \pm 1.00$ of oleic acid. The low-value PV index indicates that oxidation is well developed and that hydroperoxides have already been decomposed and transformed (Adrian et al., 1998), indicating that salting conditions accelerate lipid oxidation, which is consistent with previous reports (Smith et al., 1988). Furthermore, it was also reported that a significant role in the oxidative deterioration of salted fish was played by enzymatic oxidation (Cho et al., 1989). The highest value of the saponification index was registered for sample $\mathrm{S}$, reflecting its high content of short and medium-chain fatty acids.

Furthermore, the highest free fatty acid content was obtained in Sample D. Previous research found that salt had no inhibitory effect on lipases, which are responsible for the release of free fatty acids (Perez-Villareal and Pozo, 1992). This could mean that more unsaturated fatty acids were produced and were subjected to oxidative hydrolysis at the double bonds. The resulting substances, primarily ketones, and aldehydes, appear to be largely responsible for the products' flavor, odor, and taste (ElSebaiy and Metwalli, 1989).

Moreover, the proximate composition showed that the protein content varied between $1.28 \pm 0.35 \%$ and $1.37 \pm 0.63 \%$. But the total lipid, moisture, and ash contents showed a wide variation.

The fat content of anchovy flesh can differ not only between species but also within species from a single catch. This is due to the various stages of maturity (Pigott and Tucker, 1987). The difference in the observations could also be attributed to the higher salt content in sample D than in others. In most fish, particularly pelagic species, the total sum of the two main constituents (moisture and lipid) accounts for approximately $78-80 \%$ of the total weight. This sum is lower for the three samples in the present study. Earlier studies have also found that lipid content varies slightly (Shiriskar et al., 2010a; 2010b).

The data also revealed an inverse relationship between moisture content and fat content, which is consistent with previous studies that investigated the relationship between fat and water content (Gökoglu et al., 1999; Šimat and Bogdanović, 2012). The authors reported a very strong negative correlation between these two parameters and concluded that the existence of such a relationship between fat and water content would allow the fat content to be estimated using the moisture content. This would not replace the standard procedures for precise measurement of fat content; however, it would allow processors to make an accurate estimate of fat content.

The dry matter varied significantly between $42.5 \pm 0.1 \%$ and $47.5 \pm 0.1 \%$. The value of sample $\mathrm{S}$ was among the aforementioned samples. As shown in the table, there is a clear relation between salting, moisture, and dry matter contents, which is an inversely proportional relation.

Lower protein content and higher levels of ash and salt compared with previously reported analyses were found (Hernández-Herrero et al., 1999). On one hand, higher values of ash content, which estimate the mineral composition as well as the amount of residual salt in fish products could be attributed to high salt content, fish size, and possibly bone fragments that were not removed from anchovy samples during processing (Selmi et al., 2010). On the other hand, the protein content was found to be lower. Previous research has shown that solubilized proteins (as a result of the salting process) have an additional osmotic effect and contribute to the equilibrium state (Czerner and Yeannes, 2010). According to Nketsia-Tabiri and Sefa-Dedeh (1995), the tilapia salting process results in protein loss. High salt concentration inside the fish during salting causes a loss of soluble proteins and a 
loss of water holding capacity, resulting in protein denaturation (Kong et al., 2008).

The salt content of the three samples varies significantly as well. In sample $\mathrm{S}$, the salt content was the lowest and the highest was in sample D. These high levels of salt content can be attributed to traditional preparing conditions as well as moisture uptake due to salt's hydrostatic moisture during storage (Dewi et al., 2011). The process of anchovy salting includes the diffusion of salt into the fish and the elimination of water via osmosis. The loss of moisture from the fish due to osmosis resulted in a decrease in moisture content as well as an increase in ash and salt content in the final product (Hernández-Herrero et al., 2002; Majumdar and Basu, 2010). Furthermore, the rate of salt penetration in the muscle is highly influenced by fat content, the freshness of the fish, flesh thickness, surface/volume ratio, and temperature (Clucas, 1982). We suggest that the freshness of the fish in sample S slightly reduced the rates of absorption of salt. Fish chemical composition varies greatly between species and individuals, depending on starvation and intensive food intake periods, as well as external factors such as temperature and salinity (Huss, 1995; Zlatanos and Laskaridis, 2007). The salt content in our study is considerably higher than that reported in numerous other studies (Ababouch and El Marrakchi, 2009; Czerner and Yeannes, 2014; Zang et al., 2019). This could be due to the uncontrolled and unregulated salting process applied according to the artisanal method.

Table 2. Values of trace mineral elements and heavy metals in salted-ripened anchovies.

\begin{tabular}{|l|c|c|c|}
\hline \multirow{2}{*}{} & S & Samples & I \\
\cline { 2 - 4 } & Trace mineral elements (ppm) \\
\hline Zinc (Zn) & $0.2219 \pm 0.002^{\mathrm{a}}$ & $0.4056 \pm 0.032^{\mathrm{b}}$ & $0.3344 \pm 0.015^{\mathrm{c}}$ \\
\hline Manganese (Mn) & $0.0562 \pm 0.001^{\mathrm{a}}$ & $0.0351 \pm 0.005^{\mathrm{b}}$ & $0.0066 \pm 0.003^{\mathrm{c}}$ \\
\hline Iron (Fe) & $0.1351 \pm 0.010^{\mathrm{a}}$ & $0.2091 \pm 0.022^{\mathrm{b}}$ & $0.0777 \pm 0.034^{\mathrm{c}}$ \\
\hline Copper (Cu) & $0.0247 \pm 0.017^{\mathrm{a}}$ & $0.0332 \pm 0.022^{\mathrm{a}}$ & $0.0570 \pm 0.013^{\mathrm{a}}$ \\
\hline \multicolumn{4}{|c|}{ Heavy metals (ppm) } \\
\hline Lead (Pb) & $0.0264 \pm 0.002^{\mathrm{a}}$ & $0.0966 \pm 0.004^{\mathrm{b}}$ & $0.1142 \pm 0.009^{\mathrm{c}}$ \\
\hline Chromium (Cr) & $0.0256 \pm 0.092^{\mathrm{a}}$ & $0.0584 \pm 0.111^{\mathrm{a}}$ & $0.0531 \pm 0.102^{\mathrm{a}}$ \\
\hline Cadmium (Cd) & $0.0212 \pm 0.001^{\mathrm{a}}$ & $0.0119 \pm 0.003^{\mathrm{a}}$ & $0.0132 \pm 0.001^{\mathrm{a}}$ \\
\hline
\end{tabular}

${ }^{\mathrm{a}-\mathrm{c}}$ Values in the same line and labelled with different letters differ significantly $(p<0.01)$.

\section{Mineral composition}

Fish is a good source of minerals that are highly needed for the normal functioning of the body. Trace minerals $\mathrm{Zn}, \mathrm{Mn}, \mathrm{Fe}$, and $\mathrm{Cu}$, were present in the range of $0.0066 \pm 0.003$ to $0.4056 \pm 0.032 \mathrm{ppm}$ in the fish (Table 2). Mineral and metal content can vary depending on the surrounding environment (Sen et al., 2011). Zn was the main mineral noticed in all samples with the highest level found in sample I, followed by iron (Fe) with an important amount recorded for sample I. Our results are lower than those reported by several authors
(Mol, 2011; Galaţchi et al., 2017; Afandi et al., 2018; Sofoulaki et al., 2018).

As shown in the table above, cadmium and lead were lower than the allowed levels of the EU legislation $(0.30 \mu \mathrm{g} / \mathrm{g}$ or $0.30 \mathrm{ppm})$ and chromium was lower than the content registered by Chandrashekar and Deosthale, (1993) and Afandi et al. (2018) who reported a value of $69.3 \mu \mathrm{g} / 100 \mathrm{~g}$ and $0.27 \pm 0.442 \mu \mathrm{g} / \mathrm{g}$, respectively.

Variations in metal bioaccumulation between species have been attributed primarily to different diets and trophic levels (Metian et al., 2013; Renieri et al., 2014). During its 
reproductive cycle, anchovy consumes only foods with high-energetic value, which increases its feeding intensity (Karachle and Stergiou, 2013). Finally, various intrinsic parameters such as body size, age, sex (Sarkar et al., 2008) as well as proximate composition (lipid and protein contents) (Kalantzi et al., 2016; Sofoulaki et al., 2018) have also been proposed to explain differences in bioaccumulation or metal load among different species.

\section{Fatty acid composition}

There were changes in the fatty acid profiles (Table 3). Saturated Fatty Acids (SFA) are the most common fatty acids found in all samples. The major saturated fatty acids (SFA) were C16:0 and C18:0 with the highest percentage of C16:0. This finding is consistent with previous research, which reported $\mathrm{C} 16: 0$ to be the most abundant fatty acid in anchovies (Bayir et al., 2006) and almost all fish species (Özogul et al., 2007). Similarly, the monounsaturated fatty acids (MUFA) and polyunsaturated fatty acids (PUFA) contents showed a higher proportion in the anchovies collected from the surface and deep layers, respectively. The PUFA increased as the depth increased. Among the individual fatty acids, $\mathrm{C} 16: 0$ and $\mathrm{C} 18: 1$ were predominant in all samples. $\mathrm{C} 2: 0, \mathrm{C} 16: 0$, and $\mathrm{C} 18: 1$ decreased with depth, whereas C18:0 and C18:2 increased. In addition, only sample D contained Docosahexaenoic acid (DHA; C22:6) with a percent of $2.42 \%$ while the Eicosapentaenoic acid (EPA; C20:5) content, which was present only in the two samples I and $\mathrm{D}$, showed a higher content in sample $\mathrm{D}$, with a percentage of $1.18 \pm 0.24 \%$. According to Bayir et al. (2006), anchovy contains $11.68 \%$ EPA and $25.85 \%$ DHA. In addition, Zlatanos and Laskaridis (2007) found that EPA and DHA levels in anchovy ranged from 2.46 to $12.4 \%$, and 12.23 to $32.46 \%$, respectively, depending on the season. Saglik and Imre (2001) determined EPA $(0.86 \mathrm{~g} / 100 \mathrm{~g})$ and DHA $(1.56 \mathrm{~g} / 100 \mathrm{~g})$ in anchovy. Our results are closer to those obtained by Zlatanos and Laskaridis (2007) in DHA value and Saglik and Imre (2001) in EPA content.

Table 3. Fatty acid composition of salted-ripened anchovies.

\begin{tabular}{|c|c|c|c|}
\hline Fatty acids (\%) & \multicolumn{3}{|c|}{ Samples } \\
\hline & $\mathbf{S}$ & I & $\mathbf{D}$ \\
\hline \multicolumn{4}{|c|}{ Saturated fatty acids (SFA) } \\
\hline Oxalic acid (C2:0) & $1.47 \pm 0.00^{\mathrm{a}}$ & $0.61 \pm 0.01^{\mathrm{b}}$ & $0.41 \pm 0.01^{\mathrm{c}}$ \\
\hline Caplrylic acid (C8:0) & nd & nd & $0.17 \pm 0.00$ \\
\hline Capric acid (C10:0) & $2.02 \pm 0.08$ & nd & $0.18 \pm 0.13$ \\
\hline Lauric acid (C12:0) & nd & nd & $0.26 \pm 0.08$ \\
\hline Pentadecylic acid (C15:0) & nd & nd & $1.63 \pm 0.11$ \\
\hline Palmitic acid (C16:0) & $42.03 \pm 0.10^{\mathrm{a}}$ & $38.24 \pm 0.06^{\mathrm{a}}$ & $36.21 \pm 0.15^{\mathrm{a}}$ \\
\hline Margaric acid (C17:0) & nd & nd & $1.73 \pm 0.13$ \\
\hline Stearic acid (C18:0) & $8.78 \pm 0.18^{a}$ & $11.11 \pm 0.27^{\mathrm{b}}$ & $13.19 \pm 0.07^{\mathrm{c}}$ \\
\hline Arachidic acid (C20:0) & nd & nd & $0.35 \pm 0.15$ \\
\hline \multicolumn{4}{|c|}{ Monounsaturated fatty acids (MUFA) } \\
\hline Hexadecanoic acid $\left(\right.$ C16 $\left.\Delta^{7}\right)$ & nd & nd & $0.65 \pm 0.00$ \\
\hline Palmitoleic acid $\left(\mathrm{C}^{26} \Delta^{9}\right)$ & $1.99 \pm 0.01$ & nd & $0.23 \pm 0.01$ \\
\hline Oleic acid $\left(\mathrm{C} 18 \Delta^{9}\right)$ & $29.46 \pm 0.00^{\mathrm{a}}$ & $22.42 \pm 0.03^{b}$ & $22.24 \pm 0.07^{\mathrm{c}}$ \\
\hline Vaccenic acid $\left(C 18 \Delta^{11}\right)$ & nd & nd & $3.60 \pm 0.05$ \\
\hline Gondoic acid $\left(\mathrm{C} 20^{11}\right)$ & nd & nd & $0.27 \pm 0.00$ \\
\hline \multicolumn{4}{|c|}{ Polyunsaturated fatty acids (PUFA) } \\
\hline Octadecadienoic acid $\left(\mathrm{C} 18 \Delta^{8,11}\right)$ & $2.05 \pm 0.33^{\mathrm{a}}$ & $4.01 \pm 0.08^{b}$ & $4.70 \pm 0.03^{c}$ \\
\hline
\end{tabular}




\begin{tabular}{|l|c|c|c|}
\hline Eicosapentaenoic acid $\left(\mathbf{C ~ 2 0} \mathbf{\Delta}^{\mathbf{5 , 8 , 1 1 , 1 4 , 1 7}}\right)$ & nd & $1.10 \pm 0.10$ & $1.18 \pm 0.24$ \\
\hline Docosahexaenoic acid $\left(\mathbf{C ~ 2 2 ~} \mathbf{\Delta}^{\mathbf{4 , 7 1 0 , 1 3 , 1 6 , 1 9}}\right)$ & nd & nd & $2.42 \pm 0.17$ \\
\hline$\sum$ SFA & $54.30 \pm 0.36$ & $49.96 \pm 0.34$ & $54.13 \pm 0.83$ \\
\hline$\sum$ MUFA & $31.45 \pm 0.01$ & $22.42 \pm 0.03$ & $26.99 \pm 0.13$ \\
\hline$\sum$ PUFA & $2.05 \pm 0.33$ & $5.11 \pm 0.18$ & $8.30 \pm 0.44$ \\
\hline
\end{tabular}

nd: not detected, ${ }^{\text {a-c }}$ Values in the same line and labelled with different letters differ significantly $(p<0.01)$.

Anchovy, Atlantic herring, and both farmed and wild salmon contain, in decreasing order, 2055 to $1840 \mathrm{mg} / 100 \mathrm{~g} \mathrm{EPA}+\mathrm{DHA}$, while Atlantic mackerel, bluefish, Atlantic sardines, and trout contain from 1203 to $936 \mathrm{mg} / 100 \mathrm{~g}$ (Mozaffarian and $\mathrm{Wu}, 2011$ ).

Therefore, it is very important to underline that there was a depth effect on the whole quality characteristics of the fish related to the effect of pressure on the salting and ripening process of anchovies. According to previous reports, the main issue with the vat or barrel salting method is product irregularity because the height of the barrel and the pressure exerted by weight can create different salt concentrations at different levels in the same barrel. To avoid this, the upper layers should receive nearly twice the amount of salt as the bottom layers. Furthermore, brining, at a level of about $70 \%$, is a faster method of preserving fish. The lower the salt concentration and the fatter the fish is, the longer the period of brining required to ensure extended shelf life will be. The principal problem encountered here is that, as the fish absorbs salt from the brine and releases water from the tissues, the brine becomes diluted. Salt must therefore be added regularly (periodically) and the solution stirred frequently to ensure that the added salt does not settle down (Curtis, 1993). In our case, and based on an informal discussion with the vendor, this depth effect was mainly ascribed to the processing technique as to how the salting was applied. His information indicates that the upper layers received the same amount of salt as the bottom layers.

Previous studies, as previously mentioned, had found a negative correlation between fat and moisture; in our study, we found the same kind of relationship, but not only between the aforementioned two parameters. There was also an inverse relationship between ash and moisture, salt and moisture, and free fatty acid and moisture contents. The other thing to observe is the direct relation between crude protein and moisture content. It is necessary to note that all of these results are deeply connected with the difference in depth levels, from the superficial to the deeper one. In the same line, we noticed a clear increase with increasing depth levels in the poly-unsaturated fatty acid profile. There is no recent data that explains clearly this influence on the proximate composition of our traditional salted-ripened anchovy, but it is clear that the difference in level from which we collected our samples was the significant factor.

\subsection{Microbiological flora analysis}

As shown in Table 1, counts of aerobic mesophilic bacteria ranged from $2.0 \times 10^{4} \pm 1.0$ to $4.0 \times 10^{4} \pm 1.1 \mathrm{CFU} / \mathrm{g}$, and lactic acid bacteria counts were between $1 \times 10^{6} \pm 0.7$ and $1.3 \times 10^{7} \pm$ $0.1 \mathrm{CFU} / \mathrm{g}$. Yeasts and mould colonies were only found in sample S. None of the total and thermotolerant coliforms, staphylococci, and sulfito-reducing Clostridium were detected. The obtained results were in agreement with the microbiological criteria limits fixed by the Official Journal of the Algerian Republic (2017). It is clear from the results that the almost complete absence of spoilage and pathogenic flora is mainly due to the preservative effect of high levels of salt, which results in a decrease in water activity, thereby promoting less availability to microbial attack and an improvement of functional properties (Santiago and Maurizio, 2002).

The count of halophilic bacteria in final salt concentrations of $5 \%$ and $10 \%(\mathrm{w} / \mathrm{v})$ was between $1.23 \times 10^{3} \pm 0.83$ and $2.64 \times 10^{3} \pm 0.55$ $\mathrm{CFU} / \mathrm{g}$ and $1.12 \times 10^{3} \pm 1.00$ and $1.43 \times 10^{3} \pm$ $0.59 \mathrm{CFU} / \mathrm{g}$, respectively (Table 1 ). Previous data reported that the halophilic flora varies 
between $1.0 \times 10^{4} \mathrm{CFU} / \mathrm{g}$ and $6.4 \times 10^{4} \mathrm{CFU} / \mathrm{g}$ at salt concentrations between 5 and $10 \%$ after 73 days of anchovy's maturation (Czerner and Yeannes, 2014). This halophilic population of anchovy represents the bacterial load present in the marine environment; halophilic bacteria naturally occur in the outer layer of the skin, on the gills, and intestines of marine fish (Prescott et al., 1996). Processing environments such as handling, storage, and practical methods for preserving quality, including the salting process, could also affect halophilic count in fish.

A gradual increase was observed in halophilic bacterial count from the superficial to the deeper part (Table 1). This variation in counts could be firstly related to the initial concentration of microorganisms in the presalting stage where halophilic bacteria from salt could develop to a certain extent before being in contact with anchovies (Perez et al., 2018), and secondly due to the gradual increase in salinity created by the depth and the salting processing technique, which therefore gives higher to a lower count in halophilic microflora. During the salted anchovy ripening process, the halophilic microflora was found to be dominated by moderate and extremely halophilic bacteria, showing an important role in the ripening process (Czerner and Yeannes, 2014; Felix et al., 2016; Perez et al., 2018; 2020).

\subsection{Sensory analysis}

In terms of organoleptic quality, the overall acceptability of fish, as measured on an 8-point quality scale (Filsinger et al., 1982), was 4.20, 4.76, and 5.80 for samples I, D, and S, respectively. The fish was rated regular organoleptically, though the average sensory scores of the samples varied slightly between $3.12 \pm 1.05$ and $4.08 \pm 0.09$, corresponding to a semi-ripened product. This could be due to variations in the fish's time-temperature history. Our scores are lower than those reported by Czerner and Yeannes (2013), who recorded a mean sensory score of 5.6, 5.1, and 4.5 .

\section{Conclusions}

In conclusion, salted-ripened anchovy samples showed low protein content, high levels of ash and salt, and a wide variation in lipid content. These findings could be attributed to the traditional preparing conditions. As a result, traditional methods of preparation should be inspected, especially regarding the amount and the quality of added salt, raw material, as well as fish to salt ratio. On the other hand, there was an evident correlation between the depth levels from where the samples were collected, the halophilic bacterial count, and the poly-unsaturated fatty acid profile, which could constitute very useful information to initiate a comprehensive study on this topic.

\section{References}

Ababouch, L., El Marrakchi, A. (2009). Elaboration des semi-conserves d'anchois ; aspect économique, techniques et hygiéniques. FAO Document technique sur les pêches et l'aquaculture, 525, 1-90 (in French).

Adrian, J., Potus, J., Poiffatt, A., Dauvillier, P. (1998). Introduction à l'analyse nutritionnelle des denrées alimentaires, Ed. Lavoisier, Tec \& Doc: Paris. Pp.1-254 (in French).

Afandi, I., Talba, S., Benhra, A., Benbrahim, S., Chfiri, R., Labonne, M., Masski, H., Laë, R., De Morais, L.T., Bekkali, M., Bouthir, F. Z. (2018). Trace metal distribution in pelagic fish species from the north-west African coast (Morocco). International Aquatic Research, 10 (2), 191-205. https://doi.org/10.1007/s40071018-0192-7.

AOAC. Association of Official Analytical Chemists (1990). Official methods of analysis of the Association of the Analytical Chemists. $15^{\text {th }}$ Edition, Washington, DC.

AOAC. Association of Official Analytical Chemists (1995). Official methods of analysis of the Association of the Analytical 
Chemists. $16^{\text {th }}$ Edition, Gaithersburg, M.D, USA.

AOAC. Association of Official Analytical Chemists (2000). Official methods of analysis of the Association of the Analytical Chemists. $17^{\text {th }}$ Edition, Gaithersburg, M.D, USA.

AOCS. (1993). Official Methods and Recommended Practices of the American Oil Chemists' Society, AOC Press. Washington, DC.

Arrignon, J. (1966). L'anchois (Engraulis encrasicolus) des cotes d'Oranie. Revue des travaux de l'Institut des pèches maritimes (0035-2276) (ISTPM), 30 (4), 317-342.

Bayir, A., Haliloğlu, H., Sirkecioğlu, A.N., Aras, N.M. (2006). Fatty acid composition in some selected marine fish species living in Turkish waters. Journal of the Science of Food and Agriculture, 86, 163-168. https://doi.org/10.1002/jsfa.2295.

Chandrashekar, K., Deosthale, Y.G. (1993). Proximate composition, amino acid, mineral, and trace element content of the edible muscle of 20 Indian fish species. Journal of Food Composition and Analysis, 6 , 195-200. https://doi.org/10.1006/jfca.1993.1021.

Cho, S.Y., Endo, Y., Fujimoto, K., Kaneda, T. (1989). Oxidative deterioration of lipids in salted and dried sardine during storage at $5^{\circ} \mathrm{C}$. Bulletin of the Japanese Society for the Science of Fish, 55, 541-544. https://doi.org/10.2331/suisan.55.541.

Clucas, I.J. (1982). Salting of fish: salt and methods. In Fish Handling, Preservation and Processing: Part 2 (pp. 4-8). Report of the Tropical Products Institute, London.

Curtis, R.I. (1993). Garum and Salsamenta: Production and Commerce in Materia Medica. In: L'antiquité classique, Tome 62. Pp. 498-499.

Czerner, M. Yeannes, M.I. (2013). Modeling the effect of temperature and lipid content on anchovy (Engraulis anchoita) salting kinetics. Journal of Food Engineering, 115, 164-172. https://doi.org/10.1016/j.jfoodeng.2012.10. 004

Czerner, M., Yeannes, M.I. (2010). Brining kinetics of different cuts of anchovy (Engraulis anchoita). International Journal of Food Science \& Technology, 45 (10), 2001-2007. https://doi.org/10.1111/j.13652621.2010.02361.x.

Czerner, M., Yeannes, M.I. (2014). Bacterial Contribution to salted Anchovy (Engraulis anchoita Hubbs \& Marinni, 1935) Ripening Process. Journal of Aquatic Food Product Technology, 23 (2),

102-114. https://doi.org/10.1080/10498850.2012.697 537.

Dewi, R.S., Huda, N., Ahmad, R. (2011). Changes in the physicochemical properties, microstructure and sensory characteristics of shark dendeng using different drying methods. American Journal of Food Technology, 6 (2), 149-157. DOI: 10.3923/ajft.2011.149.157.

El-Sebaiy, L.A., Metwalli, S.M. (1989). Changes in some chemical characteristics and lipid composition of salted fermented Bouri fish muscle (Mugil cephalus). Food Chemistry, $31 \quad$ (1), 41-50. https://doi.org/10.1016/03088146(89)90149-0.

FAO. (2014). The State of World Fisheries and Aquaculture. FAO Fisheries and Aquaculture Department.

Felix, M.M., Czerner, M., Ameztoy, I., Ramírez, E., Yeannes, M.I. (2016). Investigation of Halococcus morrhuae in salted-ripened anchovy products. International Food Research Journal, 23 (6), 2668-2674.

Filsinger, B., Barassi, C.A., Lupín, H.M., Trucco, R.E. (1982). An objective index for the evaluation of the ripening of salted anchovy. International Journal of Food Science \& Technology, 17, 193-200. https://doi.org/10.1111/j.13652621.1982.tb00175.x.

Filsinger, B.E. (1987). Effect of pressure on the salting and ripening process of 
anchovies (Engraulis anchoita). Journal of Food Science, 52 (4), 919-921. https://doi.org/10.1111/j.1365-

2621.1987.tb14242.x.

Galaţchi, M., Oros, A., Coatu, V., Costache, M., Coprean, D., Galaţchi, L.D. (2017). Pollutant bioaccumulation in anchovy (Engraulis encrasicolus) tissue, fish species of commercial interest at the Romanian Black Sea coast. Ovidius University Annals of Chemistry, 28, 11-17. DOI: 10.1515/auoc-2017-0003.

Gökoglu, N., Özden, Ö., Erkan, N., Baygar, T., Metin, S. (1999). Seasonal variation in fat content of anchovy (Engraulis encrasicolus). International Journal of Food Science \& Technology, 34, 401-402. https://doi.org/10.1046/j.13652621.1999.00285.x.

Goulas, A.E., Kontominas, M.G. (2005). Effect of salting and smoking-method on the keeping quality of chub mackerel (Scomber japonicus): biochemical and sensory attributes. Food Chemistry, 93, 511-520. https://doi.org/10.1016/j.foodchem.2004.09 .040 .

Hernández-Herrero, M.M., Roig-Sagués, A.X., López-Sabater, E.I., Rodriguez-Jerez, J.J., Mora-Ventura, M.T. (1999). Total volatile basic nitrogen and other physicochemical and microbiological characteristics as related to ripening of salted anchovies. Journal of Food Science, 64, 344-347. https://doi.org/10.1111/j.1365-

2621.1999.tb15897.x.

Hernández-Herrero, M.M., Roig-Sagués, A.X., López-Sabater, E.I., Rodríguez-Jerez, J.J., Mora-Ventura, M.T. (2002). Influence of raw fish quality on some physicochemical and microbiological characteristics as related to ripening of salted anchovies (Engraulis encrasicholus L.). Journal of Food Science, 67 (7), 2631-2640. https://doi.org/10.1111/j.13652621.2002.tb08790.x.

Huss, H.H. (1988). Fresh fish-quality and quality changes, FAO Fisheries Series, 29, 28-59. Rome, Italy.
Huss, H.H. (1995). Quality and quality changes in fresh fish, FAO Fisheries Technical Paper, 348, 20-92. Rome, Italy.

ICMSF. (1983). International Commission on Microbiological Specifications for Foods. Microorganisms in foods I. Techniques of microbiological analyses. Spain: Acribia.

Kalantzi, I., Pergantis, S.A., Black, K.D., Shimmield, T.M., Papageorgiou, N., Tsapakis, M., Karakassis, I. (2016). Metals in tissues of seabass and seabream reared in sites with oxic and anoxic substrata and risk assessment for consumers. Food Chemistry, 194, 659-670. https://doi.org/10.1016/j.foodchem.2015.08 .072 .

Karachle, P.K., Stergiou, K.I. (2013). Feeding and ecomorphology of three clupeoids in the North Aegean Sea. Mediterranean Marine Science, 15 (1), 9-26. https://doi.org/10.12681/mms.350.

Kong, F., Oliveira, A., Tang, J., Rasco, B., Crapo, C. (2008). Salt effect on heatinduced physical and chemical changes of salmon fillet $(O$. gorbuscha). Food Chemistry, $106 \quad$ (3), 957-966. https://doi.org/10.1016/j.foodchem.2007.07 .008 .

Lleonart, J., Maynou, F. (2003). Fish stock assessments in the Mediterranean: state of the art. Scientia Marina, 67 (1), 37-49. DOI: $10.3989 /$ scimar.2003.67s 137 .

Llorente Holgado, R., Altonaga Zubiaga, M., Peral Díez, I., Ibargüen Salaverri, M., Gartzia Palacios, I. (2007, September). Salting dynamics for anchovy (Engraulis encrasicholus) with salt replacers. Proceedings in the European Congress of Chemical Engineering (ECCE-6), Copenhagen.

Majumdar, R.K., Basu, S. (2010). Characterization of the traditional fermented fish product Lona ilish of Northeast India. Indian Journal of Traditional Knowledge, 9 (3), 453-458.

Metian, M., Warnau, M., Chouvelon, T., Pedraza, F., Rodriguez Baena, A.M., Bustamante, P. (2013). Trace element 
bioaccumulation in reef fish from New Caledonia: influence of trophic groups and risk assessment for consumers. Marine Environmental Research, 87-88, 26-36. https://doi.org/10.1016/j.marenvres.2013.03 .001 .

Mol, S. (2011). Determination of trace metals in canned anchovies and canned rainbow trouts. Food and Chemical Toxicology, 49, 348-351.

https://doi.org/10.1016/j.fct.2010.11.005.

Mozaffarian, D., Wu, J.H. (2011). Omega-3 fatty acids and cardiovascular disease: effects on risk factors, molecular pathways, and clinical events. Journal of the American College of Cardiology, 58, 20472067.

https://doi.org/10.1016/j.jacc.2011.06.063.

NF EN ISO 12966-4. (2015). Animal and vegetable fats and oils-Gas chromatography of fatty acid methyl esters-Part 4: determination by capillary gas chromatography. Classification index: T60233-4.

NF ISO 4832. (2006). Microbiology of Food and Animal Feeding Stuffs-Horizontal Method For The Enumeration Of Coliforms-Colony Count Technique. Association Française de Normalisation, AFNOR.

NF V04-404. (2001). Meat, meat products and fishery products-Determination of total ashViandes, produits à base de viandes et produits de la pêche. Association Française de Normalisation, AFNOR.

Nketsia-Tabiri, J., Sefa-Dedeh, S. (1995). Optimization of process, conditions and quality of salted dried tilapia (Oreochromis niloticus) using response surface methodology. Journal of Science of Food and Agriculture, 69 (1), 117-127. https://doi.org/10.1002/jsfa.2740690118.

Official Journal of the Algerian Republic. 2 July 2017, N³9, 11-32.

Ormanci, H.B., Colakoglu, F.A. (2015). Nutritional and sensory properties of salted fish product, lakerda. Cogent Food \&
Agriculture, 1, $1008348 . \quad$ DOI: 10.1080/23311932.2015.1008348.

Özogul, Y., Özogul, F., Alagoz, S. (2007).

Fatty acid profiles and fat contents of commercially important seawater and freshwater fish species of Turkey: a comparative study. Food Chemistry, 103, 217-223.

https://doi.org/10.1016/j.foodchem.2006.08 .009 .

Perez, S., Czerner, M., Patat, M.L., Zaritzky, N.E., Murialdo, S.E., Yeannes, M.I. (2018). Monitoring the characteristics of cultivable halophilic microbial community during salted-ripened anchovy (Engraulis anchoita) production. International Journal of Food Microbiology, 286, 179-189. DOI: 10.1016/j.ijfoodmicro.2018.08.013.

Perez, S., Murialdo, S. E., Ameztoy, I. M., Zaritzky, N. E., Yeannes, M. I. (2020). New insights into halophilic prokaryotes isolated from salting-ripening anchovies (Engraulis anchoita) process focused on histamine-degrading strains. Extremophiles, 24 (5), 787-796. DOI: 10.1007/s00792-02001194-w.

Pigott, G.M., Tucker, B.W. (1987). Science opens new horizons for marine lipids in human nutrition. Food Reviews International, 3 (1/2), 105-138. https://doi.org/10.1080/8755912870954080 9.

Pons-Sánchez-Cascado, S., Vidal-Carou, M.C., Nunes, M.L., Veciana-Nogués, M.T. (2006). Sensory analysis to assess the freshness of Mediterranean anchovies (Engraulis encrasicholus) stored in ice. Food Control, 17, 564-569. https://doi.org/10.1016/j.foodcont.2005.02. 016.

Prescott, L.M., Harley, J.P. Klein, D.A. (1996). Antimicrobial chemotherapy. In Microbiology, $3^{\text {th }}$ Edition, 657-671. London: WCB Publishers.

Renieri, E.A., Alegakis, A.K., Kiriakakis, M., Vinceti, M., Ozcagli, E., Wilks, M.F., Tsatsakis, A.M. (2014). Cd, $\mathrm{Pb}$ and $\mathrm{Hg}$ biomonitoring in fish of the Mediterranean 
region and risk estimations on fish consumption. Toxics, 2 (3), 417-442. DOI: 10.3390/toxics2030417.

Rodríguez-Jerez, J.J., Lopez-Sabater, E.I., Roig-Sagues, A.X., Mora-Ventura, M.T. (1993). Evolution of histidine decarboxylase bacterial groups during the ripening of Spanish semi-preserved anchovies. Journal of Veterinary Medicine Series $\quad B, \quad 40, \quad 533-543$. https://doi.org/10.1111/j.14390450.1993.tb00174.x.

Saglik, S., Imre, S. (2001). $\omega 3$-Fatty Acids in Some Fish Species from Turkey. Journal of Food Science, 66 (2), 210-212. DOI: 10.1111/j.1365-2621.2001.tb11318.x.

Santiago, P. A., Maurizio, U. (2002). Effect of brine pretreatment of frozen horse mackerel (Trachurus trachurus). European Food Research Technology, 215 (2), 91-95. http://dx.doi.org/10.1007/s00217-0020530-1.

Sarkar, S.K., Cabral, H., Chatterjee, M., Cardoso, I., Bhattacharya, A.K., Satpathy, K.K., Alam, M.A. (2008). Biomonitoring of heavy metals using the bivalve Molluscs in Sunderban mangrove wetland, northeast coast of Bay of Bengal (India): possible risks to human health. Clean-Soil Air Water, 36 (2), 187-194. https://doi.org/10.1002/clen.200700027.

Selmi, S., Bouriga, N., Cherif, M., Toujani, M., Trabelsi, M. (2010). Effects of drying process on biochemical and microbiological quality of silverside (fish) Atherina lagunae. International Journal of Food Science and Technology, 45, 11611168. https://doi.org/10.1111/j.13652621.2010.02249.x.

Sen, I., Shandil, A., Shrivastava, V.S. (2011). Study for Determination of Heavy Metals in Fish Species of the River Yamuna (Delhi) by Inductively Coupled PlasmaOptical Emission Spectroscopy (ICP-OES). Advances in Applied Science Research, 2 (2), 161-166.

Shiriskar, D.A., Khedkar, G.D., Sudhakara, N.S. (2010a). Preparation of pickled products from anchovies (Stolephorus sp.) and studies on quality changes during storage. Journal of Food Processing and Preservation 34 , 176-190. https://doi.org/10.1111/j.17454549.2008.00332.x.

Shiriskar, D.A., Khedkar, G.D., Sudhakara, N.S. (2010b). Preparation of boiled and dried products from anchovies (Stolephorus sp.) and studies on quality changes during storage. Journal of Food Processing and Preservation, 34, 73-86. https://doi.org/10.1111/j.17454549.2008.00280.x.

Sikorski, Z.E., Kolakiwska, A., Burt, J.R. (1990). Postharvest biochemical and microbial changes. In: Z.E. Sikorski, (Editor.), Seafood, Resources, nutritional composition and preservation (pp. 55-76). CRC Press: Inc. Boca Raton, Florida.

Šimat, V., Bogdanović, T. (2012). Seasonal changes in proximate composition of anchovy (Engraulis encrasicolus, L.) from the central Adriatic. Acta Adriatica (00015113), 53 (1), 125-132.

Smith, G., Hanson, S., Hole, M. (1988). Lipid oxidation and associated browning in Indonesian salted-dried catfish (Arius thallasinus). Fish Technical News. p 11.

Sofoulaki, K., Kalantzi, I., Machias, A., Mastoraki, M., Chatzifotis, S., Mylona, K., Pergantis, S.A., Tsapakis, M. (2018). Metals and elements in sardine and anchovy: Species specific differences and correlations with proximate composition and size. Science of the Total Environment, 645 , 329-338. https://doi.org/10.1016/j.scitotenv.2018.07. 133

Subov, N.N. (1931). Oceanographical Tables. Moscow: USSR Oceanographic Institute Hydrometeorological Commission.

Torreblanca, M., Rodriguez Valera, F., Juez, G., Ventosa, A., Kamekura, M., Kates, M. (1986). Classification of non-alkaliphilic halobacteria based on numerical taxonomy and polar lipid composition and description of Haloarcula gen.nov. and Halopherax 
gen.nov. Systematic and Applied

Microbiology, 89-99.

https://doi.org/10.1016/S0723-

2020(86)80155-2.

Zang, J., Xu, Y., Xia, W Regenstein, J.M. (2019). Quality, functionality, and microbiology of fermented fish: a review, Critical Reviews in Food Science and Nutrition, 60 (7), 1228-1242. DOI: 10.1080/10408398.2019.1565491.

Zlatanos, S., Laskaridis, K. (2007). Seasonal variation in the fatty acid composition of three Mediterranean fish-sardine (Sardina pilchardus), anchovy (Engraulis encrasicolus) and picarel (Spicara smaris). Food Chemistry, 103, 725-728. https://doi.org/10.1016/j.foodchem.2006.09 .013 .

\section{Acknowledgements}

We would like to thank the Algerian Ministry of Higher Education and Scientific Research, the laboratory of Quality Control and Analyses of the University of Jijel and the Department of Genetics, Microbiology, and Statistics, Faculty of Biology of University of Barcelona, Spain. 